\title{
Cancer diagnosis and treatment of children and dogs: coping strategies used by parents and owners in teaching hospitals
}

\author{
Diagnóstico de câncer e tratamento de crianças e cães: \\ estratégias de enfrentamento utilizados por pais e tutores em \\ hospitais universitários
}

\author{
Luciane Cristina Vieira" ${ }^{1 *}$ Emerson Antonio Contesini² \& José Roberto Goldim³ \\ ' Veterinarian, DSc., Programa de Pós-Graduação em Ciências Veterinárias, Faculdade de Medicina Veterinária, Universidade \\ Federal do Rio Grande do Sul (UFRGS), Porto Alegre, RS, Brazil. \\ 2 Veterinarian, DSc., Faculdade de Medicina Veterinária, UFRGS, Porto Alegre, RS, Brazil. \\ ${ }^{3}$ Biologist, DSc., Hospital de Clínicas de Porto Alegre, Porto Alegre, RS, Brazil.
}

\begin{abstract}
This paper aimed to gain insight into and to compare various strategies deployed by parents and owners for coping with both cancer diagnosis and corresponding treatment for both children and dogs. Crosssectional study of the data collected from parents of children with cancer on chemotherapy at the In-Patient Unit of the Pediatric Oncology Service at Hospital de Clínicas de Porto Alegre and owners of dogs with cancer on chemotherapy at the Oncology Unit of Veterinary Clinics Hospital at Universidade Federal do Rio Grande do Sul. A semistructured interview was conducted with the 44 subjects on the impact of the diagnosis and treatment. They answered a questionnaire adapted from the Coping Strategies Inventory by Folkman and Lazarus. Data were analyzed using mixed methods, that is, statistical analysis and the content analysis proposed by Bardin. The Inventory scales were analyzed to compare parents and owners. Three of the eight scales showed statistically significant differences: responsibility acceptance ( $\mathrm{P}=0.002)$, escape-avoidance $(\mathrm{P}=0.001)$ and positive reappraisal $(\mathrm{P}=0.005)$. The main differences were found in the scales related to emotion, because parents showed both guilt and need to find a way to turn that situation into something positive. The main goal of both parents and owners was patient care and treatment. They set a course of action and pursued it, in spite of the suffering brought by the situation. The ability to reassess the situation positively was observed in both groups, as their discourse after coping with was that of who has learned to appreciate life more.
\end{abstract}

Keywords: cancer diagnosis, coping, human being-animal bond, parents-children relationships.

\section{Resumo}

Este artigo teve como objetivo compreender e comparar as várias estratégias de enfrentamento de pais e tutores frente ao diagnóstico e tratamento de câncer em crianças e cães. Foi realizado um estudo transversal com dados coletados de pais de crianças com câncer em quimioterapia na Unidade de Pacientes Internos do Serviço de Oncologia Pediátrica no Hospital de Clínicas de Porto Alegre e tutores de cães com câncer em quimioterapia na Unidade de Oncologia do Hospital de Clínicas Veterinárias na Universidade Federal do Rio Grande do Sul. Os 44 participantes realizaram entrevistas semiestruturadas abordando o impacto deste diagnóstico e tratamento, e responderam ao questionário adaptado do Inventário de Estratégias de Coping de Folkman e Lazarus. Os dados foram analisados por meio de métodos mistos, ou seja, com análise estatística e emprego da técnica de análise de conteúdo de Bardin. A análise dos fatores do Inventário comparou pais e tutores. Dos oito fatores avaliados, três tiveram diferença estatisticamente significativa: aceitação de responsabilidade $(P=0,002)$, fuga e esquiva $(P=0,001)$ e reavaliação positiva $(P=0,005)$. As principais diferenças observadas foram nos fatores relacionados à emoção, pois os pais demonstraram maior sentimento de culpa, desejo de que a doença desaparecesse e necessidade de encontrar uma maneira de transformar a situação em algo positivo. Pais e tutores tiveram como objetivo cuidar e tratar os pacientes, sendo que traçaram um plano de ação e o seguiram, apesar do sofrimento causado pela situação. A capacidade de reavaliar a situação de forma positiva foi vista nos dois grupos, pois, após o enfrentamento da situação, as falas eram de quem aprendeu a dar maior valor ao viver.

Palavras-chave: diagnóstico de câncer, enfrentamento, vínculo ser humano-animal, relação pais-filhos.
How to cite: Vieira, L. C., Contesini, E. M., \& Goldim, J. R. (2021). Cancer diagnosis and treatment of children and dogs: coping strategies used by parents and owners in teaching hospitals. Brazilian Journal of Veterinary Medicine, 43, e002220. https://doi.org/10.29374/2527-2179.bjvm002220

Received: November 02,2020 Accepted: January 13, 2021.

\section{${ }^{*}$ Correspondence \\ Luciane Cristina Vieira \\ Programa de Pós-Graduação em Ciências Veterinárias, Faculdade de Medicina Veterinária, Universidade Federal do Rio Grande do Sul - UFRGS \\ Av. Bento Gonçalves, 9090, Agronomia CEP 90540-000 - Porto Alegre (RS) Brasil E-mail: lutinavieira@ymail.com}




\section{Introduction}

Types of family have changed due to the current social dynamics, resulting in changes in legislation (Instituto Brasileiro de Geografia e Estatística, 2019). The inclusion of pets as members of the family has been an innovation, characterizing a multi-species family. Emotional bonds, that bring together parents, children and even pets, have replaced familial bonds (Família, 2017).

Emotional bonds are very relevant for the family dynamics. Cancer diagnosis of a family member can change the relationship among the family, as well as how they communicate and sort out everyday issues. Changes in behavior result from the surprise and stress caused by the diagnosis (Pereira \& Branco, 2016).

The process of a child becoming ill comes with repercussions that make both the child and the family fragile and vulnerable. When this process is represented by the overload and the stigma that come with child cancer, it is even more distressing (Amador et al., 2013). Cancer puts the patients and their family members in a condition of fragility because of its stigma, difficulties in dealing with the situation, and concerns about its consequences to the patient and the rest of the family (Pereira \& Branco, 2016). The interpretations of reality affect how people hypothesize about the future and about themselves. Predictions of the future can be completely negative in cases of cancer diagnosis, in which the subject is not able to consider more favorable results. That can cause dysfunctional or maladaptive behavior (Rosa \& Lopes, 2013). On the other hand, cancer diagnosis of a pet also mobilizes the family. Due to the new meaning given to human-animal interaction, the number of owners who seek cancer treatment for their pets is increasingly higher (Mason, 2016). The same study demonstrated that the existing proximity and emotional bond shift focus from end-of-life care, represented by euthanasia, to other options, such as surgery, chemotherapy and palliative care. Veterinary patients can be seen enjoying a good quality of life, in spite of their illness (Mason, 2016).

The individual's assessment of the situation will determine the strategies to be used in the moments of confrontation with the illness (Kristensen et al., 2010).

To date, there is not a prospective study in literature comparing the repercussion of cancer diagnosis in families with pediatric patients and the ones with veterinary patients. This study aims to assess the impact of cancer diagnosis and chemotherapy on parents of pediatric patients and on owners of veterinary patients.

\section{Material and methods}

A cross-sectional mixed methods study was performed, employing both qualitative and quantitative approaches. A stochastic sampling model was used to determine a sample of 44 subjects of age, who were picked from two groups: parents of pediatric patients and owners of dogs, both children and dogs being cancer patients submitted to chemotherapy. Data were collected at the Hospital de Clínicas de Porto Alegre (HCPA) and the Veterinary Hospital of the Universidade Federal Rio Grande do Sul (HCV-UFRGS). The subjects were identified by "P" (parents) and "T" (owners). The sample size was determined using the program WINPEPI 11.65 (Hetts \& Lagoni, 1990).

All subjects authorized the study after the consent process. A semistructured interview was conducted to assess the impact of chemotherapy on the life of the patient's family members. The Coping Strategies Inventory by Folkman and Lazarus was also used (Savóia et al., 1996). This Inventory rates eight scales: confrontation; withdrawal; self-control; social support; responsibility acceptance; escape-avoidance; problem solving; and positive reappraisal.

The qualitative analysis of the data transcribed from the interviews employed the content analysis proposed by Bardin (1977). The program NVivo 12 analyzed the frequency of words through word clouds and dendrograms. 


\section{Statistical analysis}

The quantitative analysis used to characterize the groups was conducted using the program SPSS 20.0. The Chi-squared test and the Chi-squared test with Yates correction were used to compare categorical variables, as needed. The categories with a higher frequency than expected were detected through an analysis of adjusted residuals. To compare the averages, the Student's t-test was used for independent samples, and the analysis of covariance (ANCOVA) was used to adjust for age. The significance level was set to 5\% $(P=0.05)$.

\section{Results}

There were significant differences across age $(P<0.001)$, education $(P<0.001)$ and occupation $(P=0.002)$ of the subjects. The parents were younger, mostly with basic education and not economically active. On the other hand, owners had higher education and were mostly self-employed professionals or had a formal job.

The analysis of covariance (ANCOVA) of the eight scales of the Coping Strategies Inventory demonstrated that five scales didn't show statistically significant differences in the averages of the answers $(P>0.05)$, and the other three showed these differences $(P<0.05)$. The five scales that did not differ were: Confrontation, withdrawal, self-control, social support, and problem solving. On the scales responsibility acceptance ( $P=0.002)$, escape-avoidance ( $P=0.001)$ and positive reappraisal $(P=0.005)$, the score in the group of parents was significantly higher than in the group of owners (Figures 1 and 2). When the ANCOVA was adjusted for age, the scale responsibility acceptance was no longer significant.

When evaluating the answers to the 66 items from the Inventory on a stand-alone basis, it is possible to identify which coping strategies are more connected to the parents and which are connected to the owners.

Item 55 - "I wish I could have changed what happened or how I felt." -, regarding responsibility acceptance, had the highest option on the scale marked by 15 of the 22 parents: "I used it with a high frequency". The distribution of the answers in the group of owners was more uniform among the four choices presented $(P=0.006)$.

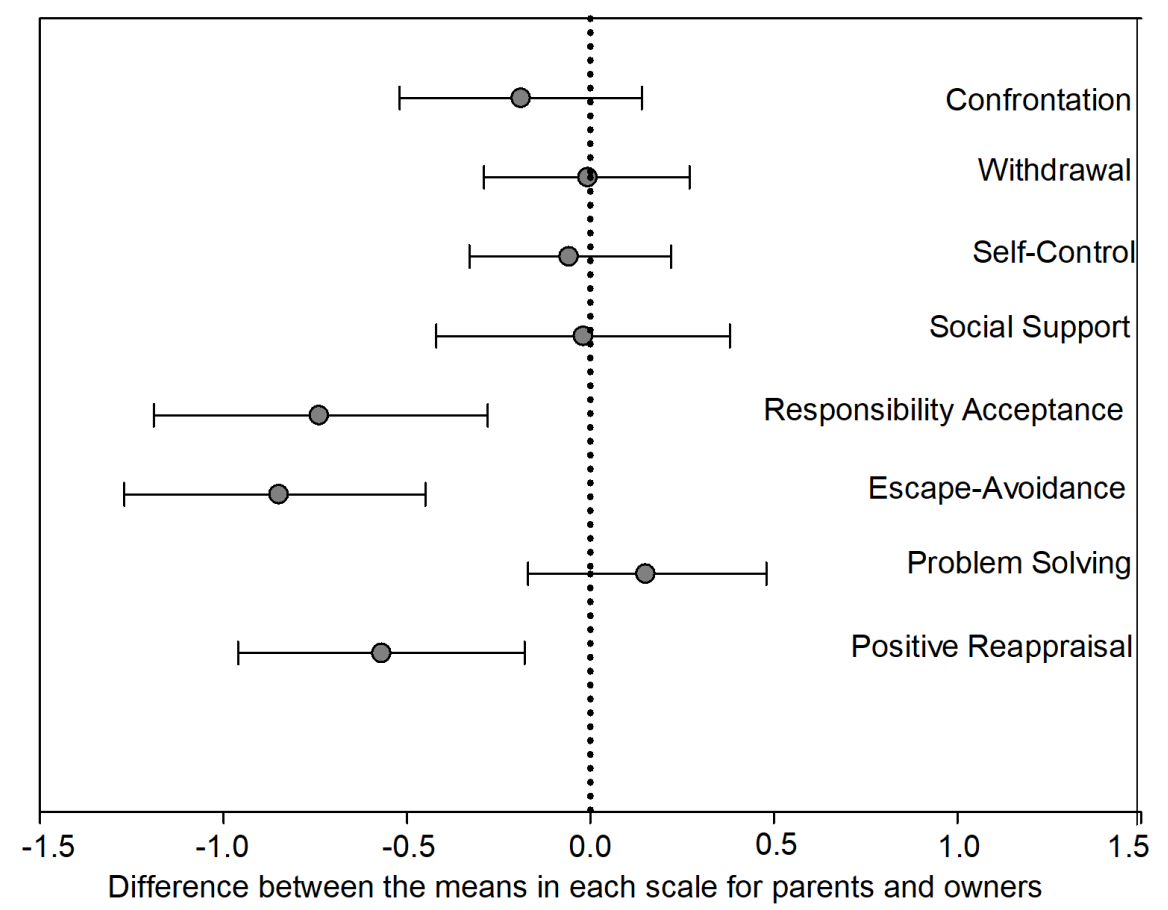

Figure 1. Graph showing the difference between the means in each scale for parents and owners, with a 95\% confidence interval (CI95\%). 


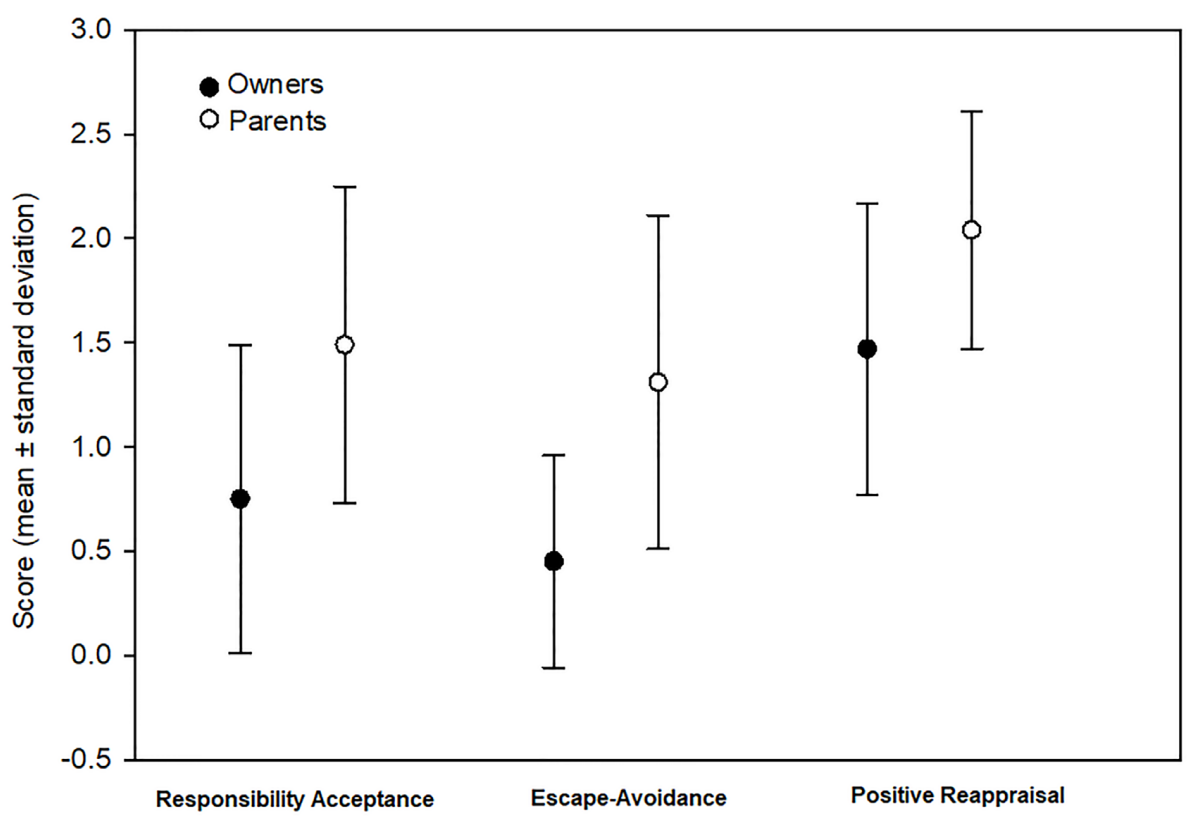

Figure 2. Graph comparing the average scores of parents and owners in the scales Responsibility Acceptance, Escape-Avoidance and Positive Reappraisal.

Item 58 - "I wanted that situation to be over or somehow disappear." - regarding escape-avoidance, also had the highest option on the scale marked by 15 parents: "I used it with a high frequency.", whereas nine owners marked the lowest option: "I did not use this strategy." ( $P=0.006)$.

Item 56 - "I changed something in myself, I changed somehow." - regards positive reappraisal. The highest option was marked by 12 of the 22 parents, whereas the answers of the owners were spread over the four choices $(P=0.01)$.

Finally, item 60 - "I prayed." -, also regarding positive reappraisal, had different answers in both groups. The highest option was marked for the strategy of prayer by 18 parents and only nine owners. On the other hand, none of the parents marked the option of not having prayed, whereas eight owners did $(P=0.01)$.

The content analysis of the answers to the guiding question of the semistructured interview - "What was the impact of the diagnosis and chemotherapy of your child or dog in your life?" - was performed using the scales of the Coping Strategies Inventory as previous assessment categories. The three categories that had different answers in the groups of parents and owners were responsibility acceptance, escape-avoidance and positive reappraisal. These results confirm the data quantitatively assessed using analysis of covariance.

Responsibility acceptance was evidenced by the doubts parents had concerning the onset of the illness and the mistakes they might have made in childcare. Owners did not show guilt related to their pet's illness.

Escape-avoidance was evidenced by the desire of the parents for the situation to be over, perhaps as a miracle. Parents also reported having isolated themselves socially and seeking comfort eating, smoking, or taking drugs or medication. Owners did not have these types of responses.

Regarding positive reappraisal, parents referred spirituality-related questions more intensely.

In the analysis of the transcript of the interviews, conducted using the program NVivo, the words well and do stood out in both groups, showing the aim of seeking treatment and the need for acting (Figures 3 and 4).

The assessment of the associations among words, using dendrograms, showed that parents associate illness to treatment, whereas owners associate illness to life. 


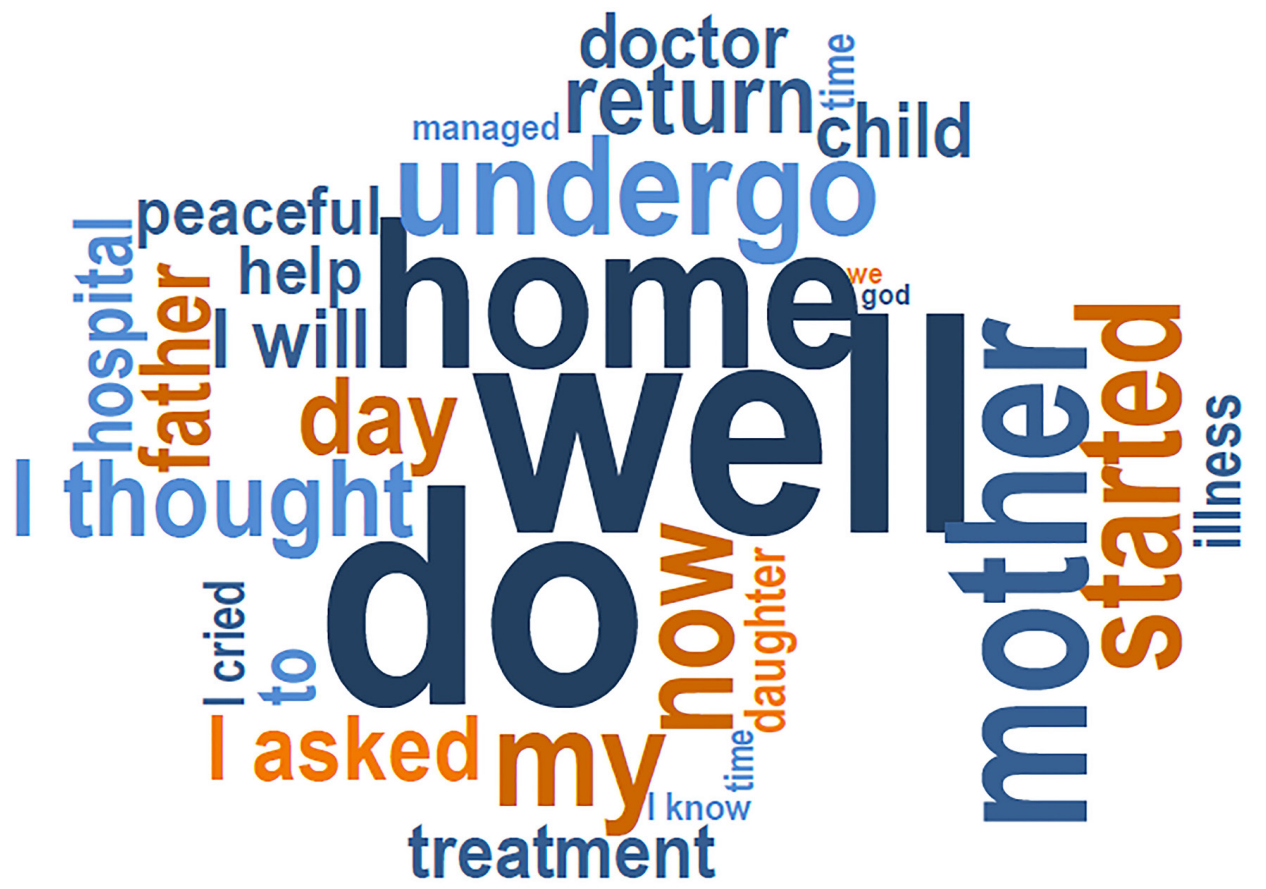

Figure 3. Word cloud generated from the transcript of the interviews with the parents, using the NVivo software. $\left(^{*}\right)$ Translator's note: the word clouds were generated from the transcript of the interviews in Portuguese and translated to English keeping the original layout. Verbs in Portuguese are inflected differently for each grammatical person, so the use of a pronoun is necessary to keep their accurate meaning in English.

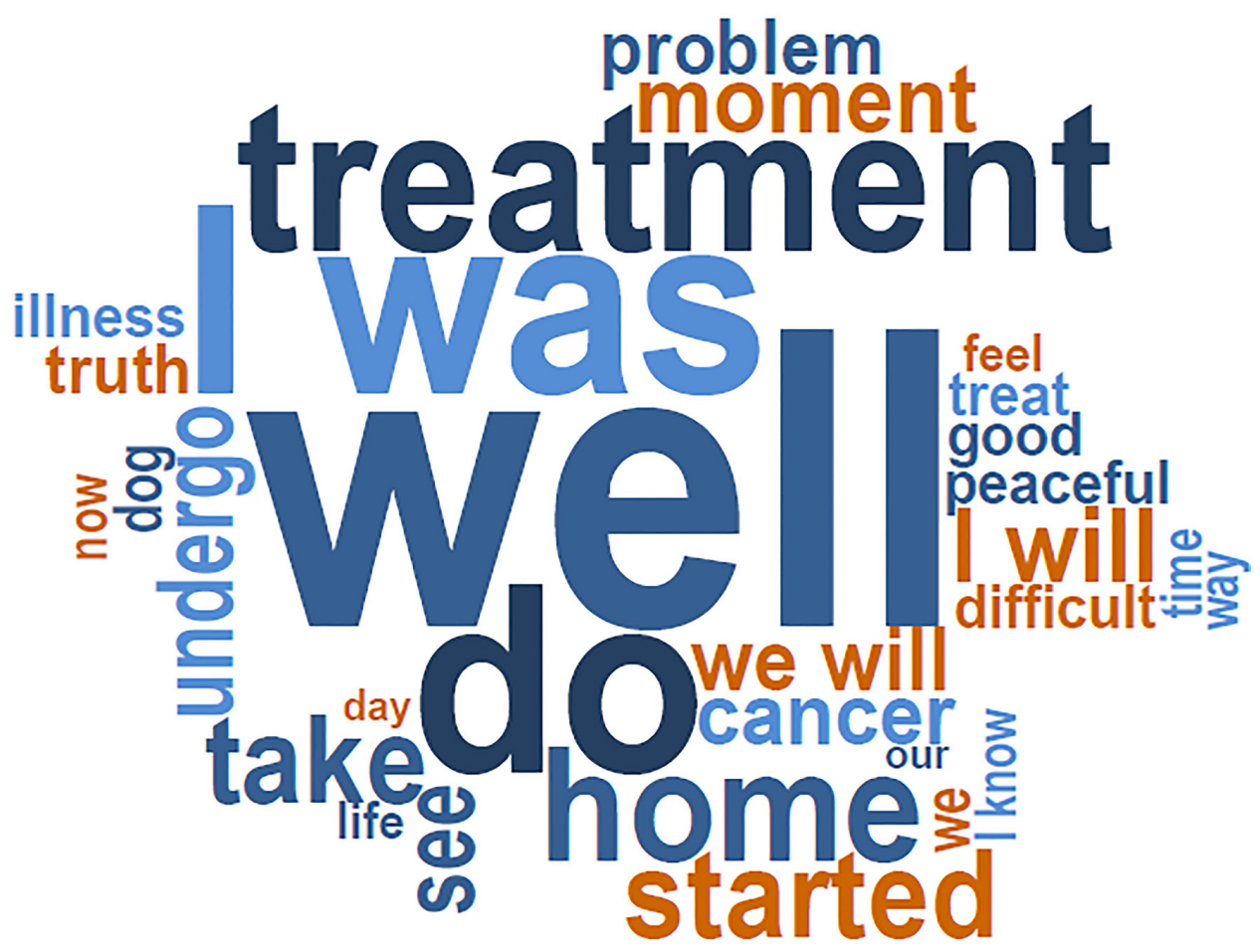

Figure 4. Word cloud generated from the transcript of the interviews with the owners, using the NVivo software. $\left({ }^{*}\right)$ Translator's note: the word clouds were generated from the transcript of the interviews in Portuguese and translated to English keeping the original layout. Verbs in Portuguese are inflected differently for each grammatical person, so the use of a pronoun is necessary to keep their accurate meaning in English. 


\section{Discussion}

The scales confrontation, withdrawal, self-control, social support, and problem solving did not show significant difference between the groups, which allowed a more balanced analysis between parents and owners.

Both sought resources to pursue what they considered necessary and did not blame anybody for the situation they were facing. Our findings are consistent with previous studies (Jarolmen, 1998) that confirm the acknowledgment of the human-animal bond existing in urban societies. This is demonstrated by the feelings of the owners towards their pets, that are considered equated with "human beings" and members of the family. Because of these characteristics, people seek an appropriate veterinary treatment to cure or prolong the life of their sick pet. People with a strong human-animal attachment usually require the understanding that they did their best to save their pets (Hetts \& Lagoni, 1990).

Neither parents nor owners found a person responsible for the situation they were going through, nor showed anger for it. The parents exposed less their feelings to others than the owners. It is important to take into consideration the mixed feelings parents have after a pediatric cancer diagnosis. The dynamics of the process full of conflicts shows the complexity of family adaptation (Van-Schoors et al., 2018). Most parents did not expose their family situation to other people, which did not happen with the owners.

The subjects did not minimize the situation and were seriously concerned about it. The moment of the diagnosis was experienced with great suffering by both groups. The finding of the illness in the family is usually described by the parents as "nothing is normal anymore", with the risk of psychological trauma and increase of negative emotions (Van-Schoors et al., 2018). The parents also reported feeling anger, guilt and sadness (Eche \& Aronowitz, 2018). Even though they intensely seek a way of hiding or eliminating their child's illness, they see no way out, therefore surrendering to the emotional impact of this situation (Amador et al., 2013).

Neither group acted as if nothing had happened, and both thought deeply about what they were going through. Negative impacts were identified on the quality of life of the parents, concerning their physical, psychological, emotional and social health, especially in the first six months after the diagnosis (Slater et al., 2018).

Both parents and owners were shocked by the situation they faced, which included changes in the family routine (Slater et al., 2018). Most parents of pediatric cancer patients admitted that their priorities had changed and that the health of their child had become the most important thing (Kim et al., 2019).

Both parents and owners knew what had to be done and consequently doubled their efforts to do what was needed, setting a course of action and focusing on it. It was found that the need for control involved planning to beat cancer, and it was paramount to follow the plan and establish routines and strategies to make it happen (Gårdling et al., 2017).

Not backing off made the fathers understand the need for their active participation in the care of their child, since the mother is overloaded in this process. These findings are consistent with a study that shows the mother as the main caregiver (Kim et al., 2019).

In neither group the subjects rushed into anything or did something irreversible following their initial impetus. Previous studies have also demonstrated this characteristic (Moreira \& Angelo, 2008). Living a period of fight for the child's life shows the extent of the mother's behaviors, that are expressed by the interactions with herself, with the child, and with all the elements involved in the experience of her child's illness, evidencing the development of her role as a mother of a child with cancer.

Both parents and owners talked to other people about the problem, seeking help and information about the situation, and talking to somebody who could do something concrete to help them. The answers of the parents confirm other studies (Gårdling et al., 2017) where it was understood that they were the connection between their child and the hospital. Obtaining relevant information provided a feeling of control and reduced uncertainty. Finding routines or strategies helped the parents manage the situations they were facing and focus on their child.

In this study, we found that the families felt welcome and looked after in both hospitals. The treatment given by the medical care team was referred positively by both groups. 
The subjects talked to somebody about how they were feeling, accepting sympathy, as in compassion, and comprehension from other people. Most subjects were supported by their social network, although many have showed feelings of loneliness and abandonment. Family support was paramount in both groups.

The families of both human and animal patients ended up bonding with the institution and with other families. In the group of parents, sharing the same difficulties brought attachment and concern with other children as well as their own. The parents also found strength in the contact with other people who have been through the same experience (Pezente et al., 2014).

Most parents and owners drastically changed their lives after the treatment of the patient started. The suffering of the parents seems to have been stronger, since they were estranged from their families and especially from their other children due to the long periods of hospitalization. The families had to leave everything behind to focus on the care of their child. The emotional pain of the parents affected their quality of life. They admitted having focused more on the sick child to the detriment of other family members, which brought more guilt and emotional strain (Kim et al., 2019).

In both groups, the subjects either changed or grew as a person, leaving this experience better than expected. Their statements demonstrated that going through the experience of having a child or pet diagnosed with cancer and submitted to chemotherapy sparked new reflections and understandings to these people.

In the scales where differences between the groups were detected, the idea of guilt of the parents is evidenced by their questionings about the onset of the illness and about where they went wrong concerning childcare. Guilt was not reported in the group of owners.

The parents criticized and rebuked themselves and wished they could have changed what had happened or how they had felt. This was not observed in the group of owners. The statements of the parents are, in a way, consistent with current literature (Anjos et al., 2015), that shows that the contact with the illness causes fear of the unknown and guilt for what is happening to their child, seeing the illness as a punishment (Teixeira \& Pereira, 2011).

The period where cancer is diagnosed is characterized by the abrupt break of routine, and the fact that it is a potentially fatal illness brings doubts about the plans for the future of the family (Teixeira \& Pereira, 2011). We found that the parents wanted the situation to be over or go away, which was not observed in the group of the owners. The parents hoped for a miracle, in contrast with most owners.

During the period of treatment, the parents had considerable pain, which persisted even after the treatment was completed. Higher anxiety and stress levels, associated with thoughts of recurrence or relapse, were observed (Al-Gamal et al., 2019).

The mothers stated that their protective behavior could avoid further suffering. The fathers showed feelings of not having given enough love to their child in the past (Al-Gamal et al., 2019).

The pain caused by the fear of the loss is also experienced by the owners. The human-animal bond can be compared to the human-human bond. Therefore, a strong attachment to a pet animal can be a predictor of the suffering an owner can experience (Merrill, 2012).

The parents seek comfort eating, smoking, or taking drugs or medication, differently from the owners. The answers from the group of parents confirm the findings of another study (Slater, 2019) where a mother states that: "As a mother, living with a child who had cancer, I know that my life has changed forever and I am still learning to live with that. I saw a doctor and we agreed that now I need a little help, with antidepressants and some appointments with psychologists to process what happened and deal with the future."

The parents tried to avoid people in general, which was not observed in the group of the owners. Another study shows that parents realized that the others had no idea of how their family felt, which resulted in more isolation. Numerous families ended up feeling segregated (Slater, 2019).

The subjects of that study rediscovered what matters in life. The answers and statements of the parents confirm another study (Van-Schoors et al., 2018) that shows a change of attitude towards life in face of the new situation. In that case, the family starts playing a more important role and things outside the family become less significant. The parents reported appreciating more the little things, valuing more the time spent with their families. 
Most parents prayed, whereas half of the owners did it. The parents showed stronger feelings related to religiosity, which were expressed by an increased faith and surrender of the illness to God's will (Amador et al., 2013).

From the data collected and analyzed in this study, the main differences were found in the scales related to emotion, because parents showed more guilt, wish that the illness went away, and need to find a way to turn that situation into something positive.

Our findings reinforce the understanding that dogs are considered important members of the family.

In both groups, the main goal was patient care and treatment. Both parents and owners set a course of action and pursued it, in spite of the suffering brought by the situation. This can be evidenced by the expressions of pain and despair, mostly in the statements of the parents. They also expressed more suffering, which can be due to the long period of hospitalization of their child, causing the distancing from the family, especially their other children.

\section{Conclusion}

Both parents and owners assessed the situation positively because, after facing it, they learned to appreciate life more. Our findings highlight the need to get both parents and owners more involved in the treatment because it brings more security, ensuring that the patients will get the care they need. The families reported feeling welcome and looked after in both hospitals.

\section{Acknowledgements}

The authors would like to thank the Universidade Federal do Rio Grande do Sul (UFRGS), Hospital de Clínicas de Porto Alegre (HCPA), the Graduate Program in Veterinary Science at UFRGS, and the Veterinary Hospital of UFRGS.

\section{Ethics approval}

This study was approved by the Research Ethics Committees at UFRGS and HCPA under CAAE: 91188518.5.0000.5327.

\section{Financial support}

None.

\section{Conflict of interests}

Nothing to declare.

\section{Authors' contributions}

All authors contributed equally to the development of this research and writing of the manuscript.

\section{Availability of complementary results}

No complementary results are available.

The study was carried out at Hospital de Clínicas de Porto Alegre and Hospital de Clínicas Veterinárias, Universidade Federal do Rio Grande do Sul - UFRGS, Porto Alegre, RS, Brasil.

\section{References}

Al-Gamal, E., Long, T., \& Shehadeh, J. (2019). Health satisfaction and family impact of parents of children with cancer: A descriptive cross-sectional study. Scandinavian Journal of Caring Sciences, 33(4), 815-823. http://dx.doi.org/10.1111/scs.12677.

Amador, D. D., Gomes, I. P., Reichert, A. P. S., \& Collet, N. (2013). Repercussões do câncer infantil para o cuidador familiar: Revisão integrativa. Revista Brasileira de Enfermagem, 66(2), 264. http://dx.doi.org/10.1590/ $\underline{\text { S0034-71672013000200017. }}$ 
Anjos, C. D., Santo, F. H. D. E., \& Carvalho, E. M. M. S. D. (2015). O câncer infantil no âmbito familiar: revisão integrativa. Revista Mineira de Enfermagem,19(1), 227-240. http://www.dx.doi.org/10.5935/1415-2762.20150018.

Bardin, L. (1977). Análise de conteúdo. Martins Fontes.

Eche, I. J., \& Aronowitz, T. (2018). Factors That Influence Parental Uncertainty and Health-Related Quality of Life in Children With Cancer: A Framework. Nursing Science Quarterly, 31(4), 362-368. http://dx.doi.org/10.1177/0894318418792896.

Família. (2017).Família multiespécieétendência mundial.http://diariodonordeste.verdesmares.com.br/cadernos/ regional/familia-multiespecie-e-tendencia-mundial-1.242833.

Gårdling, J., Törnqvist, E., Edwinson Månsson, M., \& Hallström, I. (2017). Parents' lived experiences during their children's radiotherapy. Journal of Pediatric Oncology Nursing, 34(2), 140-147. http://dx.doi. org/10.1177/1043454216646540.

Hetts, S., \& Lagoni, L. (1990). The owner of the pet with cancer. The Veterinary Clinics of North America. Small Animal Practice, 20(4), 879-896. http://dx.doi.org/10.1016/S0195-5616(90)50076-5.

Instituto Brasileiro de Geografia e Estatística - IBGE. (2019) Síntese de indicadores sociais: uma análise das condições de vida da população brasileira. https://biblioteca.ibge.gov.br/visualizacao/livros/liv98965.pdf.

Jarolmen, J.(1998). A comparison of the grief reaction of children and adults: Focusing on pet loss and bereavement. Omega, 37(2), 133-150. http://dx.doi.org/10.2190/H937-U230-X7D9-CVKH.

Kim, M. A., Yi, J., Wilford, A., \& Kim, S. H. (2019). Parenting Changes of Mothers of a Child with Cancer. Journal of Family Issues, 41(4), 460-482. http://dx.doi.org/10.1177/0192513X19881191.

Kristensen, C. H., Schaefer, L. S., \& Busnello, F. D. B. (2010). Estratégias de coping e sintomas de stress na adolescência. Estudos de Psicologia, 27(1), 21-30. http://dx.doi.org/10.1590/S0103-166X2010000100003.

Mason, S. (2016). Palliative care in small animal oncology. In Practice, 38(5), 203-217. http://dx.doi.org/10.1136/ inp.i1869.

Merrill, E. (2012). Companion Animal Loss: A Disenfranchised Form of Grief and why it's Relevant to Social Work. https://sophia.stkate.edu/cgi/viewcontent.cgi?article=1059\&context=msw_papers.

Moreira, P. L., \& Angelo, M. (2008). Becoming a mother of a child with cancer: Building motherhood. Revista Latino-Americana de Enfermagem, 16(3), 355-361. http://dx.doi.org/10.1590/S0104-11692008000300004.

Pereira, T. B., \& Branco, V. L. R. (2016). As estratégias de coping na promoção à saúde mental de pacientes oncológicos: Uma revisão bibliográfica. Revista Psicologia e Saúde, 8, 24-31. http://dx.doi.org/10.20435/2177093X2016104.

Pezente, C. C., Valvassori, E., \& Zugno, P. I. (2014). Sentimento dos pais e das crianças com câncer submetidas à quimioterapia. Inova Saúde, 3(2), 88-96. http://periodicos.unesc.net/Inovasaude/article/view/1665/1673

Rosa, R. R., \& Lopes, R. F. F. (2013). Presença de distorções cognitivas em propagandas brasileiras. Revista Brasileira de Terapias Cognitivas, 9(2), 71-80. http://dx.doi.org/10.5935/1808-5687.20130011.

Savóia, M. G., Santana, P. R., \& Mejias, N. P. (1996). Adaptação do inventário de Estratégias de Coping de Folkman e Lazarus para o português. Psicologia USP, 7(1-2), 183-201. http://dx.doi.org/10.1590/S1678-51771996000100009.

Slater, P. J. (2019). Telling the story of childhood cancer: The experience of families after treatment. Journal of Patient Experience, 7(4), 570-576. http://dx.doi.org/10.1177/2374373519870363.

Slater, P. J., Fielden, P. E., \& Bradford, N. K. (2018). The oncology family app: Providing information and support for families caring for their child with cancer. Journal of Pediatric Oncology Nursing, 35(2), 94-102. http://dx.doi.org/10.1177/1043454217741874.

Teixeira, R. J., \& Pereira, M. D. G. (2011). Impacto do câncer parental no desenvolvimento psicológico dos filhos: Uma revisão da literatura. Psicologia: Reflexão e Crítica, 24(3), 513-522. http://dx.doi.org/10.1590/ S0102-79722011000300012.

Van-Schoors, M., De Mol, J., Morren, H., Verhofstadt, L. L., Goubert, L., \& Van Parys, H. (2018). Parents' perspectives of changes within the family functioning after a pediatric cancer diagnosis: A multi family member interview analysis. Qualitative Health Research, 28(8), 1229-1241. http://dx.doi.org/10.1177/1049732317753587. 